\title{
EHHzürich
}

ETH Library

\section{Oxyleghemoglobin scavenges nitrogen monoxide and peroxynitrite \\ A possible role in functioning nodules?}

Journal Article

Author(s):

Herold, Susanna; Puppo, Alain

Publication date:

2005-12

Permanent link:

https://doi.org/10.3929/ethz-b-000030939

Rights / license:

In Copyright - Non-Commercial Use Permitted

Originally published in:

JBIC Journal of Biological Inorganic Chemistry 10(8), https://doi.org/10.1007/s00775-005-0046-9 


\section{Susanna Herold • Alain Puppo \\ Oxyleghemoglobin scavenges nitrogen monoxide and peroxynitrite: a possible role in functioning nodules?}

\begin{abstract}
It has been demonstrated that the $\mathrm{NO}^{\bullet}$ produced by nitric oxide synthase or by the reduction of nitrite by nitrate reductase plays an important role in plants' defense against microbial pathogens. The detection of nitrosyl $\mathrm{Lb}$ in nodules strongly suggests that $\mathrm{NO}^{\bullet}$ is also formed in functional nodules. Moreover, $\mathrm{NO}^{\bullet}$ may react with superoxide (which has been shown to be produced in nodules by various processes), leading to the formation of peroxynitrite. We have determined the second-order rate constants of the reactions of soybean oxyleghemoglobin with nitrogen monoxide and peroxynitrite. At $\mathrm{pH} 7.3$ and $20^{\circ} \mathrm{C}$, the values are on the order of $10^{8}$ and $10^{4} \mathrm{M}^{-1} \mathrm{~s}^{-1}$, respectively. In the presence of physiological amounts of $\mathrm{CO}_{2}$ $(1.2 \mathrm{mM})$, the second-order rate constant of the reaction of oxyleghemoglobin peroxynitrite is even larger $\left(10^{5} \mathrm{M}^{-1} \mathrm{~s}^{-1}\right)$. The results presented here clearly show that oxyleghemoglobin is able to scavenge any $\mathrm{NO}^{\bullet}$ and peroxynitrite formed in functional nodules. This may help to stop $\mathrm{NO}^{\bullet}$ triggering a plant defense reaction.
\end{abstract}

Keywords Leghemoglobin - Nitric oxide · Peroxynitrite $\cdot$ Hemoglobin $\cdot$ Kinetics $\cdot$ Mechanism

Abbreviation EPR: Electron paramagnetic resonance $\mathrm{Hb}$ : Human hemoglobin - Lb: Leghemoglobin · $\mathrm{LbFeO}_{2}$ (oxyLb): Oxyleghemoglobin .

S. Herold $(\varangle)$

Laboratorium für Anorganische Chemie, Eidgenössische Technische Hochschule,

ETH Hönggerberg, 8093 Zürich, Switzerland

E-mail: herold@inorg.chem.ethz.ch

Tel.: +41-44-6322858

Fax: + 41-44-6321090

A. Puppo

UMR CNRS-UNSA-INRA IPMSV, 400, Route des Chappes, BP167, 06903 Sophia-Antipolis Cedex, France
$\mathrm{LbFe}^{\mathrm{IV}}=\mathrm{O}($ ferrylLb): Oxoiron(IV)-leghemoglobin.

MetLb: Iron(III)leghemoglobin · Mb: Myoglobin ·

NOS: Nitric oxide synthase

\section{Introduction}

Hemoglobins, heme-containing proteins that display a conserved three-on-three arrangement of $\alpha$-helices (globin fold), have been found ubiquitously in eukaryotes and in many bacteria. Plant hemoglobins were first identified in the root nodules of legumes [1], and these proteins were therefore called leghemoglobins (Lbs). For many years it was believed that Lbs were the only hemoglobins present in plants. However, in the 1980s a new class of hemoglobins was discovered in both nodulating and non-nodulating plants [2]. At least three types of hemoglobins are now believed to be present in plants [3]. Symbiotic Lbs are found in high concentrations in the root nodules of legumes that establish a symbiosis with nitrogen-fixing bacteria [4]. The primary function of these hemoglobins is to facilitate the transport of $\mathrm{O}_{2}$ to bacteroids for ATP generation while protecting nitrogenase in the bacteroids from $\mathrm{O}_{2}$-mediated inactivation. Nonsymbiotic hemoglobins are thought to be present in all plants, albeit at much lower concentrations. These proteins have been divided into two groups, class- 1 and class- 2 hemoglobins, according to their phylogeny, protein sequences, biochemical properties, and gene expression profiles. The diverse properties of the hemoglobins belonging to these two classes suggest that class- 1 and the class- 2 proteins have different functions [5]. Class-1 hemoglobins have been proposed to have important functions in plant growth and ATP metabolism under hypoxic conditions, and are expressed in plant tissue in response to specific metabolic stresses [3]. Class-2 hemoglobins are induced in response to microorganisms and, contrary to class- 1 hemoglobins, by cytokinin treatment [5]. Compared to class-1 hemoglobins, these proteins display sequences closer to those of Lbs. Finally, the third type of plant hemoglobins 
consist of truncated hemoglobins, hemoproteins that display amino acid sequences $20-40$ residues shorter than normal hemoglobins $[6,7]$.

In animals, nitrogen monoxide ( $\mathrm{NO}^{\bullet}$, nitric oxide) was first identified as an endothelium-derived relaxing factor (EDRF), but is now recognized to regulate a variety of different functions [8]. Three isoforms of nitric oxide synthase (NOS) are responsible for the generation of $\mathrm{NO}^{\circ}$ in mammalian systems: constitutive endothelial and neuronal NOSs, and inducible NOS, which is associated with immune and inflammatory responses [9]. $\mathrm{NO}^{\bullet}$ is also produced in plants, but much less is known about the mechanism of its generation and its functions [10,11]. Evidence for the existence of a mammalian-type NOS in plants, mostly based on cross-reactions with mammalian NOS antibodies, has repeatedly been reported [12]. However, it has also been demonstrated that some of these antibodies interact with plant proteins other than NOS [13]. Alternative $\mathrm{NO}^{\bullet}$ sources may occur in plants, and one candidate is considered to be nitrate reductase [14-16]. This enzyme has been shown to transform nitrite into $\mathrm{NO}^{\circ}$ in a NADH-dependent process, which is operative when photosynthetic activity is absent or inhibited, and when nitrite can be accumulated [14, 17].

Depending on the concentration applied, both cytotoxic and protecting properties have been attributed to $\mathrm{NO}^{\bullet}$ in plants [18]. It has been demonstrated that $\mathrm{NO}^{\bullet}$ plays an important role in the mechanism of plant defenses against microbial pathogens [18-20]. Furthermore, $\mathrm{NO}^{\bullet}$ was demonstrated to be essential for the regulation of normal plant physiological processes [21]. As for mammalian [22] and bacterial [23] hemoglobins, the reaction of plant hemoglobins with $\mathrm{NO}^{\bullet}$ may also have a significant physiological function. In this context, it has been shown that both class-1 hemoglobins and $\mathrm{NO}^{\bullet}$ are produced during hypoxic stress [24]. Consequently, it has been suggested that these hemoglobins play a crucial role in modulating the levels of $\mathrm{NO}^{\circ}$. Hemoglobin can act as a $\mathrm{NO}^{\bullet}$ dioxygenase [25] and thus, by lowering the $\mathrm{NO}^{\bullet}$ concentration, prevent $\mathrm{NO}^{\bullet}$ mediated inhibition of cytochrome c oxidase in mitochondria [26, 27].

Interestingly, it has been reported that a NOS-like enzyme is present in the roots and nodules of a leguminous plant (Lupinus albus) [28]. Since $\mathrm{NO}^{\bullet}$ is an inhibitor of nitrogenase from nitrogen-fixing bacteria [29], it is not known whether $\mathrm{NO}^{\bullet}$ has a biological role in nodules. However, a nitrosyl-leghemoglobin complex $\left(\mathrm{LbFe}^{\mathrm{II}} \mathrm{NO}\right)$ has been detected in soybean [30], cowpea [31], and alfalfa [32] nodules, an observation that suggests that $\mathrm{NO}^{\bullet}$ is generated in functional nodules and that $\mathrm{Lb}$ may indeed react with it. Moreover, since superoxide may be produced in nodules by various processes [33], including Lb autoxidation [34], it is also conceivable that also peroxynitrite is formed in these organs. In animals, peroxynitrite generated from the diffusion-controlled reaction between $\mathrm{NO}^{\bullet}$ and $\mathrm{O}_{2}^{\bullet-}$ $\left((1.6 \pm 0.3) \times 10^{10} \mathrm{M}^{-1} \mathrm{~s}^{-1}\right.$ [35]) causes protein nitration and oxidative tissue damage [36].
We have recently reported that human methemoglobin (metHb) and horse heart metmyoglobin (metMb) catalyze the isomerization of peroxynitrite to nitrate, albeit not very efficiently [37]. Moreover, oxyHb and oxy $\mathrm{Mb}$ have also been shown to scavenge peroxynitrite and to prevent nitration of their own tyrosine residues as well as externally added Tyr [38-40]. We have started to investigate the reactivity of soybean leghemoglobin $(\mathrm{Lb})$ toward so-called reactive nitrogen species. In this work, we have mainly focused on oxyLb, which is the physiologically active form in the nodules. Our data show that this form can efficiently scavenge $\mathrm{NO}^{\bullet}$ and peroxynitrite; the possible roles of these reactions in the nodulation process are discussed.

\section{Materials and methods}

\section{Reagents}

Buffer solutions were prepared from $\mathrm{K}_{2} \mathrm{HPO}_{4} / \mathrm{KH}_{2} \mathrm{PO}_{4}$ (Fluka,Deisenhofen, Germany) with deionized Milli-Q water. Sodium dithionite, potassium superoxide, and hydrogen peroxide were obtained from Fluka. Sodium bicarbonate was purchased from Merck (Darmstadt, Germany). Nitrogen monoxide (Linde, Höllriegelskreuth, Germany) was passed through a $\mathrm{NaOH}$ solution and a column of $\mathrm{NaOH}$ pellets before use in order to remove higher nitrogen oxides. Nitrogen monoxide solutions were prepared as described previously [41].

\section{Peroxynitrite, carbon dioxide, and protein solutions}

Peroxynitrite was prepared either from $\mathrm{KO}_{2}$ and gaseous nitrogen monoxide according to Koppenol et al [42], or by treating tetramethylammonium superoxide with nitrogen monoxide at $-77^{\circ} \mathrm{C}$ in liquid ammonia, followed by isolation as a crystalline solid via removal of the ammonia [43]. No difference was observed between the reactivity of peroxynitrite prepared according to the two procedures. The peroxynitrite solutions, which contained variable amounts of nitrite (maximally 50\% relative to the peroxynitrite concentration) and no hydrogen peroxide, were stored in small aliquots at $-80^{\circ} \mathrm{C}$. Nitrite did not interfere with our studies, since the reactions of nitrite with oxyLb or with $\mathrm{LbFe}^{\mathrm{IV}}=\mathrm{O}$ proceed at a significantly slower rate than the corresponding reactions with peroxynitrite $[44,45]$. The stock solutions were diluted either with $0.01 \mathrm{M} \mathrm{NaOH}$ or with water, and the concentration of peroxynitrite was determined spectrophotometrically prior to each experiment by measuring the absorbance at $302 \mathrm{~nm}$ $\left(\varepsilon_{302}=1,705 \mathrm{M}^{-1} \mathrm{~cm}^{-1}\right)$ [43].

For the experiments carried out in the absence of added $\mathrm{CO}_{2}$, the buffers and the $0.01 \mathrm{M} \mathrm{NaOH}$ solutions were prepared fresh daily and thoroughly degassed. Experiments in the presence of $\mathrm{CO}_{2}$ were carried out by adding the required amount of a freshly prepared $0.5 \mathrm{M}$ 
sodium bicarbonate solution to the protein solutions as described in detail in [40]. The values for the constant of the hydration-dehydration equilibrium $\mathrm{CO}_{2}+\mathrm{H}_{2} \mathrm{O} \rightleftharpoons$ $\mathrm{H}^{+}+\mathrm{HCO}_{3}^{-}$were taken from [46], by considering the ionic strengths of the solutions. After addition of $\mathrm{CO}_{2}$ or bicarbonate, the protein solutions were allowed to equilibrate at room temperature for at least $5 \mathrm{~min}$.

Soybeans (Glycine max) were grown in a glasshouse and the $\mathrm{Lb}$ components purified from the root nodules as described previously [47]. All of the experiments reported here were carried out with $\mathrm{Lb} c_{2}$. The metLb concentration was determined by measuring the absorbance in $0.1 \mathrm{M}$ phosphate buffer $(\mathrm{pH} 7.0-7.3)$ at $404 \mathrm{~nm}$ $\left(\varepsilon_{404}=141 \mathrm{mM}^{-1} \mathrm{~cm}^{-1}\right)$. OxyLb was prepared by reducing a concentrated metLb solutions with a slight excess of sodium dithionite. The solution was purified chromatographically on a Sephadex G25 column by using a $0.1 \mathrm{M}$ phosphate buffer solution $\mathrm{pH} 7.0$ as the eluant. OxyLb solutions were prepared by diluting this stock solution with buffer, and concentrations were determined by measuring the absorbance at 411, 542 and $/$ or $575 \mathrm{~nm}\left(\varepsilon_{411}=125 \mathrm{mM}^{-1} \mathrm{~cm}^{-1}, \varepsilon_{542}=15.0\right.$ $\mathrm{mM}^{-1} \mathrm{~cm}^{-1}$ and $\varepsilon_{575}=14.8 \mathrm{mM}^{-1} \mathrm{~cm}^{-1}$ ). FerrylLb solutions were prepared as described in [48], and their concentrations were determined by measuring the absorbance at 416 or $543 \mathrm{~nm}\left(\varepsilon_{416}=97.2 \mathrm{mM}^{-1} \mathrm{~cm}^{-1}\right.$ and $\varepsilon_{543}=10.4 \mathrm{mM}^{-1} \mathrm{~cm}^{-1}$ ) [48].

\section{$\mathrm{UV} /$ visible spectroscopy}

Absorption spectra were collected in $1 \mathrm{~cm}$ cells with a UVIKON 820 spectrophotometer (Kontron, Basel, Switzerland).

\section{Stopped-flow kinetics analysis}

Single-wavelength stopped-flow studies were carried out with an Applied Photophysics (Leatherhead, UK) SX17MV or a SX18MV-R instrument. The measured reaction time courses were analyzed with Kaleidagraph (Synergy Software, Reading, PA), version 3.6.2. Rapidscan spectrophotometric studies were performed with an On-Line Instrument Systems Inc. (OLIS; Bogart, GA) stopped-flow instrument equipped with an OLIS RSM 1000 rapid scanning monochromator. The length of the cell in each of the three spectrophotometers was $1 \mathrm{~cm}$. The mixing time of the OLIS instrument is $\sim 4 \mathrm{~ms}$, whereas those of the single-wavelength instruments are $\sim 2 \mathrm{~ms}$. All of the measurements were carried out at $20{ }^{\circ} \mathrm{C}$.

Kinetics studies of the reaction of oxyLb with $\mathrm{NO}^{\bullet}$ were carried out under pseudo-first order conditions with oxyLb in excess with the Applied Photophysics instruments. Reaction time courses used for second-order rate constant determination were collected at $405 \mathrm{~nm}$. For this purpose, the $\mathrm{NO}^{\bullet}$ solutions were prepared by diluting the aqueous stock solution $(2 \mathrm{mM})$ with degassed $0.1 \mathrm{M}$ phosphate buffer ( $\mathrm{pH} 7.3$ ) directly in a Hamilton (Martinsried, Germany) SampleLock syringe and the oxyLb solutions were prepared by diluting the stock solution with degassed $0.1 \mathrm{M}$ phosphate buffer ( $\mathrm{pH}$ 7.3). The concentrations of the oxyLb solutions were determined spectrophotometrically prior to each experiment. Detection of the metLb-peroxynitrite intermediate was performed with the OLIS instrument at $\mathrm{pH}$ 9.5. Both the protein and the $\mathrm{NO}^{\bullet}$ solutions were prepared in $0.1 \mathrm{M}$ borate buffer $(\mathrm{pH} 9.5)$.

The reactions of peroxynitrite with oxyLb and with ferrylLb were first studied by rapid-scan stopped-flow spectroscopy, both in the presence and in the absence of $\mathrm{CO}_{2}$. The second-order rate constants were then determined by single-wavelength measurements at 413 (or 415) and $430 \mathrm{~nm}$. The protein solutions were prepared by diluting the oxy Lb and the ferrylLb stock solutions to the desired concentration with $0.1 \mathrm{M}$ phosphate buffer $(\mathrm{pH}$ 7.0-7.3) under aerobic conditions, in the absence or presence of added bicarbonate. Peroxynitrite solutions were prepared by diluting the stock solution immediately before use with $0.01 \mathrm{M} \mathrm{NaOH}$ to achieve the required concentration. Kinetics studies of peroxynitrite decay in the presence of different amounts of metLb were performed by single-wavelength stopped-flow spectroscopy by following the absorbance decrease at $302 \mathrm{~nm}$. For all reactions with peroxynitrite, the protein was dissolved in a $0.1 \mathrm{M}$ buffer at a $\mathrm{pH}$ slightly more acidic $(0.2-0.4 \mathrm{pH}$ units lower) than the desired final $\mathrm{pH}$, which was always measured at the end of the reaction for the control.

\section{Statistics}

The experiments reported in this article were carried out in triplicate at least, on independent days. The results are given as mean values of at least three experiments \pm the corresponding standard deviation.

\section{Results}

Kinetics studies of the reaction of oxyLb with nitrogen monoxide

The reaction between $\mathrm{NO}^{\bullet}$ and oxyLb was first studied under anaerobic conditions by rapid-scan stopped-flow spectroscopy at $\mathrm{pH} 7.3$ and $20^{\circ} \mathrm{C}$ by following the change in absorbance in the range $300-650 \mathrm{~nm}$. Upon reaction with a slight excess of $\mathrm{NO}^{\bullet}(3-10 \mu \mathrm{M})$ the characteristic absorbance maxima of oxyLb $(2-9 \mu \mathrm{M})$ at 411, 542, and $575 \mathrm{~nm}$ shifted within the mixing time essentially to those of metLb $\left(\lambda_{\max }=404,532\right.$, and $623 \mathrm{~nm}$ ) (data not shown). To determine the secondorder rate constant of this reaction, we therefore used the single-wavelength stopped-flow instrument, which has a shorter mixing time and is more suited to measuring extremely fast reactions. Because of the difficulties linked with accurately determining the 
concentrations of $\mathrm{NO}^{\bullet}$ solutions, we chose to keep the concentration of oxyLb at a large excess compared to that of $\mathrm{NO}^{\bullet}$, to maintain pseudo first-order conditions. The reaction time courses were collected at $405 \mathrm{~nm}$, one of the wavelengths at which the difference in absorbance between oxyLb and metLb is the largest $\left(\Delta \varepsilon_{405}=\sim 30 \mathrm{mM}^{-1} \mathrm{~cm}^{-1}\right)$. As shown in Fig. 1, the traces could all be fitted well to a single-exponential expression. The second-order rate constant, obtained from the linear fit of the plot of the observed pseudo first-order rate constants versus oxyLb concentration (Fig. 1) is $(8.2 \pm 0.5) \times 10^{7} \mathrm{M}^{-1} \mathrm{~s}^{-1}$. This value is very similar to that reported for the corresponding reactions of $\mathrm{NO}^{\bullet}$ with human oxyHb and horse heart oxyMb (Table 1) [49].

The reactions of $\mathrm{NO}^{\bullet}$ with oxyHb and oxyMb have been shown to proceed via the corresponding peroxynitrite iron(III) complexes (Fe ${ }^{\mathrm{III}} \mathrm{OONO}$ ), which have been characterized by UV/vis spectroscopy under alkaline conditions [49, 50]. Moreover, the hemoglobin intermediate $\mathrm{HbFe}^{\mathrm{III}} \mathrm{OONO}$ has recently been characterized under similar conditions by rapid-freeze EPR spectroscopy [50]. As observed for $\mathrm{Hb}$ and $\mathrm{Mb}$, rapidscan spectroscopic studies of the reaction of $\mathrm{NO}^{\bullet}$ with oxyLb did not show the presence of a detectable intermediate under neutral conditions ( $\mathrm{pH}$ 7.3). Interestingly, as shown in Fig. 2, the reaction of oxyLb with $\mathrm{NO}^{-}$ yields the alkaline form of metLb $\left(\lambda_{\max }=539\right.$ and $570 \mathrm{~nm}$ ) without the formation of a detectable intermediate, even under alkaline conditions $(0.1 \mathrm{M}$ borate buffer $\mathrm{pH}$ 9.5). Under identical conditions, $\mathrm{MbFe}^{\mathrm{III}} \mathrm{OONO}$ has been shown to decay to metMb and nitrate at a rate of $205 \pm 5 \mathrm{~s}^{-1}$ [49]. The $\mathrm{HbFe}^{\mathrm{III}}$ OONO

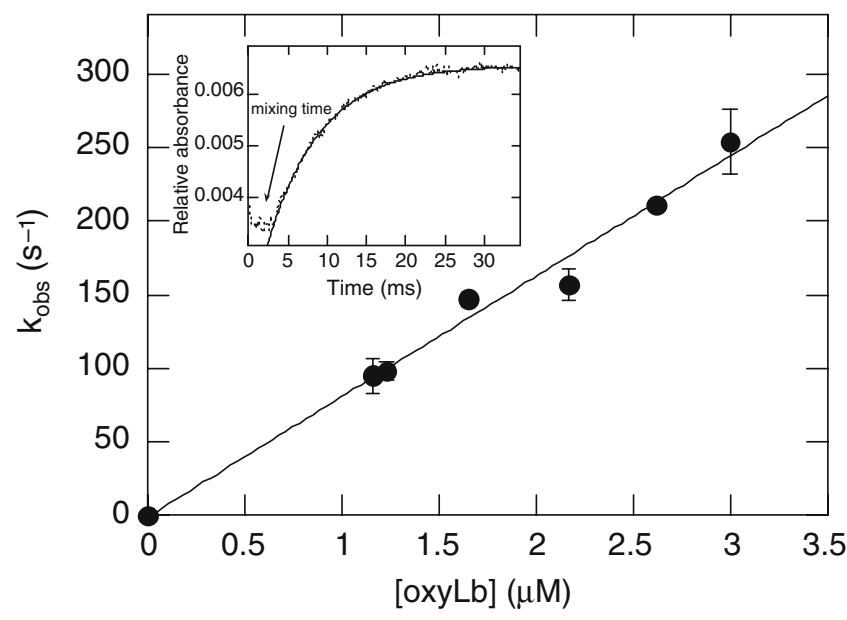

Fig. 1 Determination of the second-order rate constant for the $\mathrm{NO}^{-}$-mediated oxidation of oxyLb. Plot of $k_{\text {obs }}$ versus oxyLb concentration for the reaction between $\mathrm{NO}^{\bullet}(0.1-0.3 \mu \mathrm{M})$ and variable amounts of oxyLb, measured at $20^{\circ} \mathrm{C}$ in $0.1 \mathrm{M}$ phosphate buffer ( $\mathrm{pH}$ 7.3). Inset Reaction time course (average of ten traces) measured at $405 \mathrm{~nm}$ for the reaction of $1.65 \mu \mathrm{M}$ oxyLb with $\sim 0.16 \mu \mathrm{M} \mathrm{NO}{ }^{\bullet}$ in $0.1 \mathrm{M}$ phosphate buffer $\mathrm{pH}$ 7.3. The dotted bold line represents the experimental data, whereas the full line corresponds to the best fit to the data $\left(k_{\mathrm{obs}}=146 \pm 2 \mathrm{~s}^{-1}\right)$ complex is more stable and the two subunits decay at a rate of $47 \pm 3$ and $6.9 \pm 0.1 \mathrm{~s}^{-1}$ [49]. Recent reinvestigation of the kinetics of the decay of $\mathrm{HbFe}^{\mathrm{III}} \mathrm{OONO}$ in $0.1 \mathrm{M}$ borate buffer $(\mathrm{pH} 9.5)$ showed that the decay rate of the fast component that we reported previously $\left(36 \pm 5 \mathrm{~s}^{-1},[49]\right)$ is incorrect.

Kinetics studies of the reaction of oxyLb with peroxynitrite

The reaction between oxyLb and peroxynitrite was studied by rapid-scan UV/vis spectroscopy at $\mathrm{pH} 7.3$ and $20{ }^{\circ} \mathrm{C}$. As shown in Fig. 3a, upon reaction with peroxynitrite, the intensities of the two absorbance bands characteristic for oxyLb $\left(\lambda_{\max }=542\right.$ and $575 \mathrm{~nm}$, thin line) decreased and the spectrum of metLb $\left(\lambda_{\max }=535 \mathrm{~nm}\right.$, bold line) appeared. Two sets of isosbestic points were identified during the reaction, at 525/ $584 \mathrm{~nm}$ (Fig. 3a) and 525/611 nm (Fig. 3b), respectively.

This observation indicates that the reaction of peroxynitrite with oxyLb proceeds via an intermediate. The isosbestic points observed at the beginning of the reaction (Fig. 3a) correspond to those between the spectra of oxyLb and ferrylLb, whereas those present at the end of the reaction (Fig. 3b) correspond approximately to those between the spectra of ferrylLb and metLb. In analogy to the reaction of peroxynitrite with human oxyHb and horse heart oxyMb [39, 40, 51], our results strongly suggest that the reaction between peroxynitrite and oxyLb also proceeds in two steps via the formation of ferrylLb (Reactions 1 and 2).

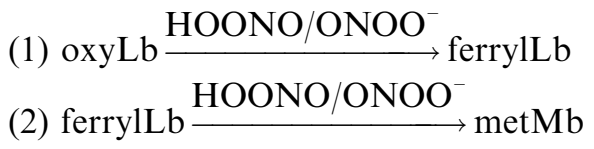

It is worth noting that the absorbance spectrum of the reaction product (the bold line in Fig. 3b) is not completely identical to that of metLb. The small differences - the slightly lower absorbance around $500 \mathrm{~nm}$ and the absorbance maximum at 539 instead of $535 \mathrm{~nm}$ - indicate that the final product is a mixture of metLb and its nitrite complex $\mathrm{LbFe}^{\mathrm{III}} \mathrm{NO}_{2}$. Nitrite, present as an impurity in the peroxynitrite solutions, is in excess relative to metLb and thus partly binds to the product but does not influence the rate of the reaction between oxyLb and peroxynitrite. At $\mathrm{pH} 7.3$ and $20{ }^{\circ} \mathrm{C}$, the second-order rate constant for nitrite binding to metLb is $(4.7 \pm 0.1) \times 10^{3} \mathrm{M}^{-1} \mathrm{~s}^{-1}$, and the absorbance maxima of $\mathrm{LbFe}^{\mathrm{III}} \mathrm{NO}_{2}$ are at 410 and $538 \mathrm{~nm}$ [45].

As shown in Fig. 4, the absorbance changes observed for the Soret band in the course of the reaction of oxyLb with an excess of peroxynitrite are also consistent with the proposed mechanism. The characteristic band for oxyLb $\left(\lambda_{\max }=411 \mathrm{~nm}\right.$, thin line $)$ decreased and the absorbance maximum of the final product $\left(\lambda_{\max }=405\right.$ $406 \mathrm{~nm}$, bold line) is very close to that of matLb $\left(\lambda_{\max }=405 \mathrm{~nm}\right)$. As discussed above, the absorbance 
Table 1 Comparison of rate constants for reactions of different forms of leghemoglobin $(\mathrm{Lb})$, human hemoglobin $(\mathrm{Hb})$, and horse heart myoglobin $(\mathrm{Mb})$ with $\mathrm{NO}^{\bullet}$ and peroxynitrite at $\mathrm{pH}$ $7.0-7.3$ and $20{ }^{\circ} \mathrm{C}$

\begin{tabular}{|c|c|c|c|}
\hline Protein & Reaction & Rate constants $\left(\mathrm{M}^{-1} \mathrm{~s}^{-1}\right)$ & Reference \\
\hline $\mathrm{Lb}$ & $\mathrm{Fe}(\mathrm{II}) \mathrm{O}_{2}+\mathrm{NO}^{\bullet}+\mathrm{H}_{2} \mathrm{O} \rightarrow \mathrm{Fe}(\mathrm{III}) \mathrm{OH}_{2}+\mathrm{NO}_{3}^{-}$ & $k=(8.2 \pm 0.5) \times 10^{7}$ & This study \\
\hline $\mathrm{Lb}$ & $\begin{array}{l}\mathrm{Fe}(\mathrm{II}) \mathrm{O}_{2}+\mathrm{HOONO} / \mathrm{ONOO}^{-} \\
\text {In the presence of } 1.2 \mathrm{mM} \mathrm{CO}_{2}\end{array} \rightarrow \mathrm{Fe}(\mathrm{IV})=\mathrm{O}$ & $\begin{array}{l}k=(5.5 \pm 0.5) \times 10^{4} \\
k=(8.8 \pm 0.9) \times 10^{5}\end{array}$ & This study \\
\hline $\mathrm{Lb}$ & 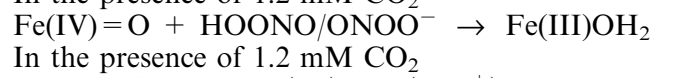 & $\begin{array}{l}k=(2.1 \pm 0.2) \times 10^{4} \\
(3.6 \pm 0.5) \times 10^{5}\end{array}$ & This study \\
\hline $\mathrm{Lb}$ & $\mathrm{HOONO} / \mathrm{ONOO}^{-} \mathrm{Fe}(\mathrm{III}) \mathrm{NO}_{3}^{-}\left(+\mathrm{H}^{+}\right)$ & $k_{\mathrm{cat}}=(1.45 \pm 0.02) \times 10^{5}$ & This study \\
\hline $\mathrm{Hb}$ & $\mathrm{Fe}(\mathrm{II}) \mathrm{O}_{2}+\mathrm{NO}^{\bullet}+\mathrm{H}_{2} \mathrm{O} \rightarrow \mathrm{Fe}(\mathrm{III}) \mathrm{OH}_{2}+\mathrm{NO}_{3}{ }^{-}$ & $k=(8.9 \pm 0.3) \times 10^{7}$ & {$[66]$} \\
\hline $\mathrm{Hb}$ & $\begin{array}{l}\mathrm{Fe}(\mathrm{II}) \mathrm{O}_{2}+\mathrm{HOONO} / \mathrm{ONOO}^{-} \rightarrow \mathrm{Fe}(\mathrm{IV})=\mathrm{O} \\
\text { In the presence of } 1.2 \mathrm{mM} \mathrm{CO}_{2}\end{array}$ & $\begin{array}{l}k=(3.3 \pm 0.1) \times 10^{4} \\
k=(3.5 \pm 0.3) \times 10^{5}\end{array}$ & [51] \\
\hline $\mathrm{Hb}$ & $\begin{array}{l}\mathrm{Fe}(\mathrm{IV})=\mathrm{O}+\mathrm{HOONO} / \mathrm{ONOO}^{-} \rightarrow \mathrm{Fe}(\mathrm{III}) \mathrm{OH}_{2} \\
\text { In the presence of } 1.2 \mathrm{mM} \mathrm{CO}_{2}\end{array}$ & $\begin{array}{l}k=(3.3 \pm 0.4) \times 10^{4} \\
k=(1.1 \pm 0.1) \times 10^{5}\end{array}$ & [51] \\
\hline $\mathrm{Hb}$ & $\mathrm{HOONO} / \mathrm{ONOO}^{-} \mathrm{Fe}(\mathrm{III}) \mathrm{NO}_{3}^{-}\left(+\mathrm{H}^{+}\right)$ & $k_{\mathrm{cat}}=(1.2 \pm 0.1) \times 10^{4}$ & [37] \\
\hline $\mathrm{Mb}$ & $\mathrm{Fe}(\mathrm{II}) \mathrm{O}_{2}+\mathrm{NO}^{\bullet}+\mathrm{H}_{2} \mathrm{O} \rightarrow \mathrm{Fe}(\mathrm{III}) \mathrm{OH}_{2}+\mathrm{NO}_{3}^{-}$ & $k=(4.4 \pm 0.1) \times 10^{7}$ & [49] \\
\hline $\mathrm{Mb}$ & $\begin{array}{l}\mathrm{Fe}(\mathrm{II}) \mathrm{O}_{2}+\mathrm{HOONO} / \mathrm{ONOO}^{-} \rightarrow \mathrm{Fe}(\mathrm{IV})=\mathrm{O} \\
\text { In the presence of } 1.2 \mathrm{mM} \mathrm{CO}_{2}\end{array}$ & $\begin{aligned} k & =(5.4 \pm 0.2) \times 10^{4} \\
k & =(4.1 \pm 0.7) \times 10^{5}\end{aligned}$ & {$[39]$} \\
\hline $\mathrm{Mb}$ & $\begin{array}{l}\mathrm{Fe}(\mathrm{IV})=\mathrm{O}+\mathrm{HOONO} / \mathrm{ONOO}^{-} \rightarrow \mathrm{Fe}(\mathrm{III}) \mathrm{OH}_{2} \\
\text { In the presence of } 1.2 \mathrm{mM} \mathrm{CO}_{2}\end{array}$ & $\begin{array}{l}k=(2.2 \pm 0.1) \times 10^{4} \\
k=(3.2 \pm 0.2) \times 10^{4}\end{array}$ & {$[39]$} \\
\hline $\mathrm{Mb}$ & $\mathrm{HOONO} / \mathrm{ONOO}^{-} \mathrm{Fe}(\mathrm{III}) \mathrm{NO}_{3}^{-}\left(+\mathrm{H}^{+}\right)$ & $k_{\text {cat }}=(2.9 \pm 0.1) \times 10^{4}$ & {$[37]$} \\
\hline
\end{tabular}

changes in the visible part of the spectrum suggest the formation of small amounts of $\mathrm{LbFe}^{\mathrm{III}} \mathrm{NO}_{2}$ $\left(\lambda_{\max }=410 \mathrm{~nm}\right)$, which may be responsible for the slight shift observed for the Soret band. The intermediate band with a maximum at $409 \mathrm{~nm}$ arises from a mixture of mainly ferrylLb and metLb.

The kinetics of the reaction between oxyLb and an excess of peroxynitrite were studied by single-wavelength stopped-flow spectroscopy under pseudo firstorder conditions. The two steps of the reaction were studied separately. The reaction time courses of the first step were measured at 413 or $414 \mathrm{~nm}$ and those of the second step at 399 or $430 \mathrm{~nm}$, close to the isosbestic points for the second and the first reaction step, respectively. As shown in Fig. 5, both time courses could be fitted to a single-exponential expression. However, the fits for the second traces had to start from the point when the first step finished (see vertical line in Fig. 5b).

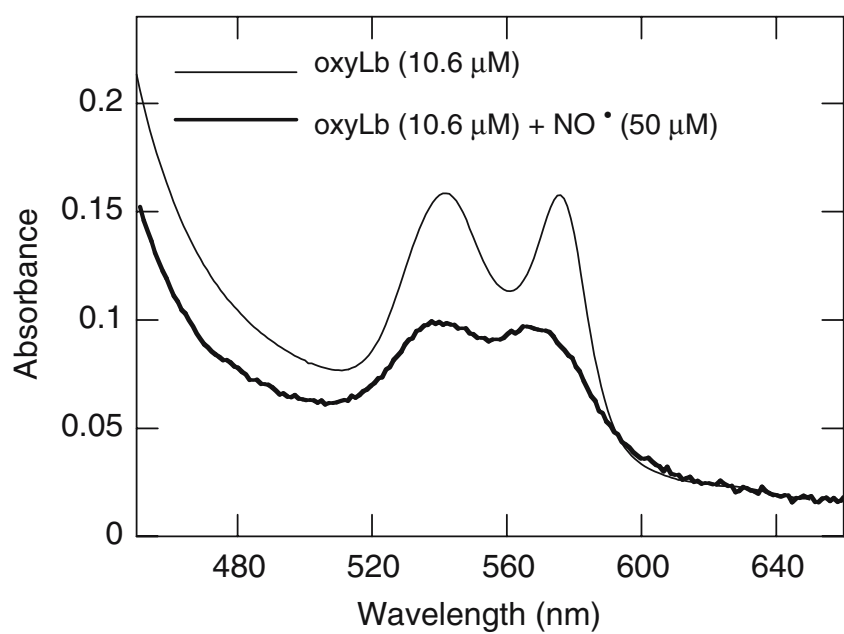

Fig. 2 Rapid-scan UV/vis spectra of the reaction of oxyLb $(10.6 \mu \mathrm{M})$ with $\mathrm{NO}^{\bullet}(\sim 50 \mu \mathrm{M})$ in $0.1 \mathrm{M}$ borate buffer $\mathrm{pH} 9.5$, $20{ }^{\circ} \mathrm{C}$. Conversion of oxyLb (thin line) to the alkaline form of metLb (bold line), collected $\sim 2$ ms after mixing
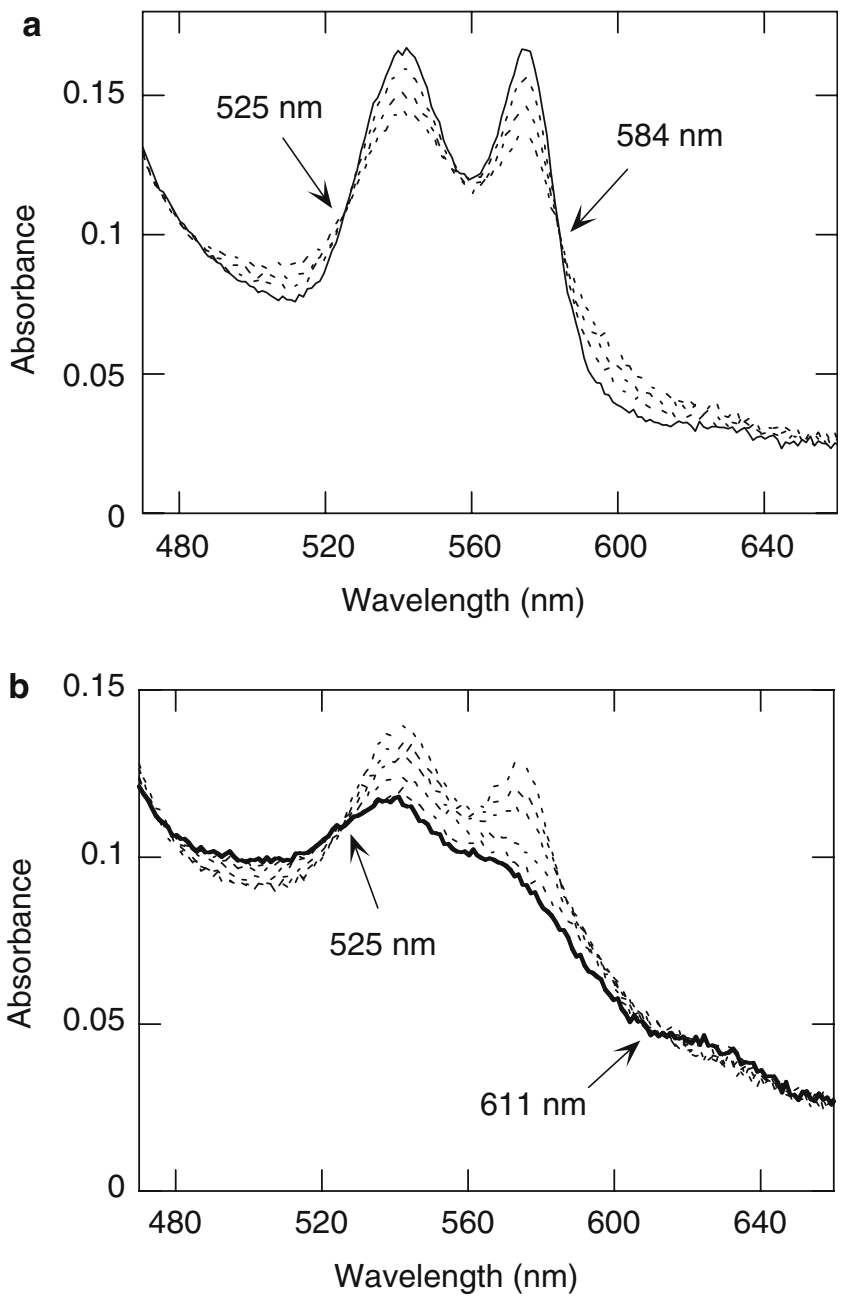

Fig. 3a-b Rapid-scan UV/vis spectra of the reaction of oxyLb $(13 \mu \mathrm{M})$ with peroxynitrite $(170 \mu \mathrm{M})$ in $0.05 \mathrm{M}$ phosphate buffer $\mathrm{pH} 7.3,20^{\circ} \mathrm{C}$. Conversion of oxyLb (thin line) to a mixture of $\mathrm{LbFe}^{\mathrm{IIII}} \mathrm{NO}_{2}$ and metLb (bold line). a The shown spectra were collected with a time interval of $100 \mathrm{~ms}$. b The shown traces were collected at 400, 500, 600, 900, 1,200, and 1,800 ms 
As shown in Fig. 6, we obtained a linear dependence of the observed rate constants on the peroxynitrite concentration for both reaction steps. The second-order rate constants obtained from the linear fits of the data for the two reaction steps are $(5.5 \pm 0.5) \times 10^{4}$ and $(2.1 \pm 0.2) \times$ $10^{4} \mathrm{M}^{-1} \mathrm{~s}^{-1}$, respectively. These values are very close to those obtained for the reaction of peroxynitrite with human oxyHb and with horse heart oxyMb under similar conditions (Table 1).

To confirm that the second step of the reaction between peroxynitrite and oxyLb corresponds to the reduction of ferrylLb to metLb, we studied the reaction of peroxynitrite with ferrylLb, prepared separately by the addition of four equivalents of $\mathrm{H}_{2} \mathrm{O}_{2}$ to deoxyLb [48]. In contrast to ferryl Hb [52], it has been shown that ferrylLb is rather stable and (among other species) does not react with $\mathrm{H}_{2} \mathrm{~S}$ [48]. Figure 7a shows that upon
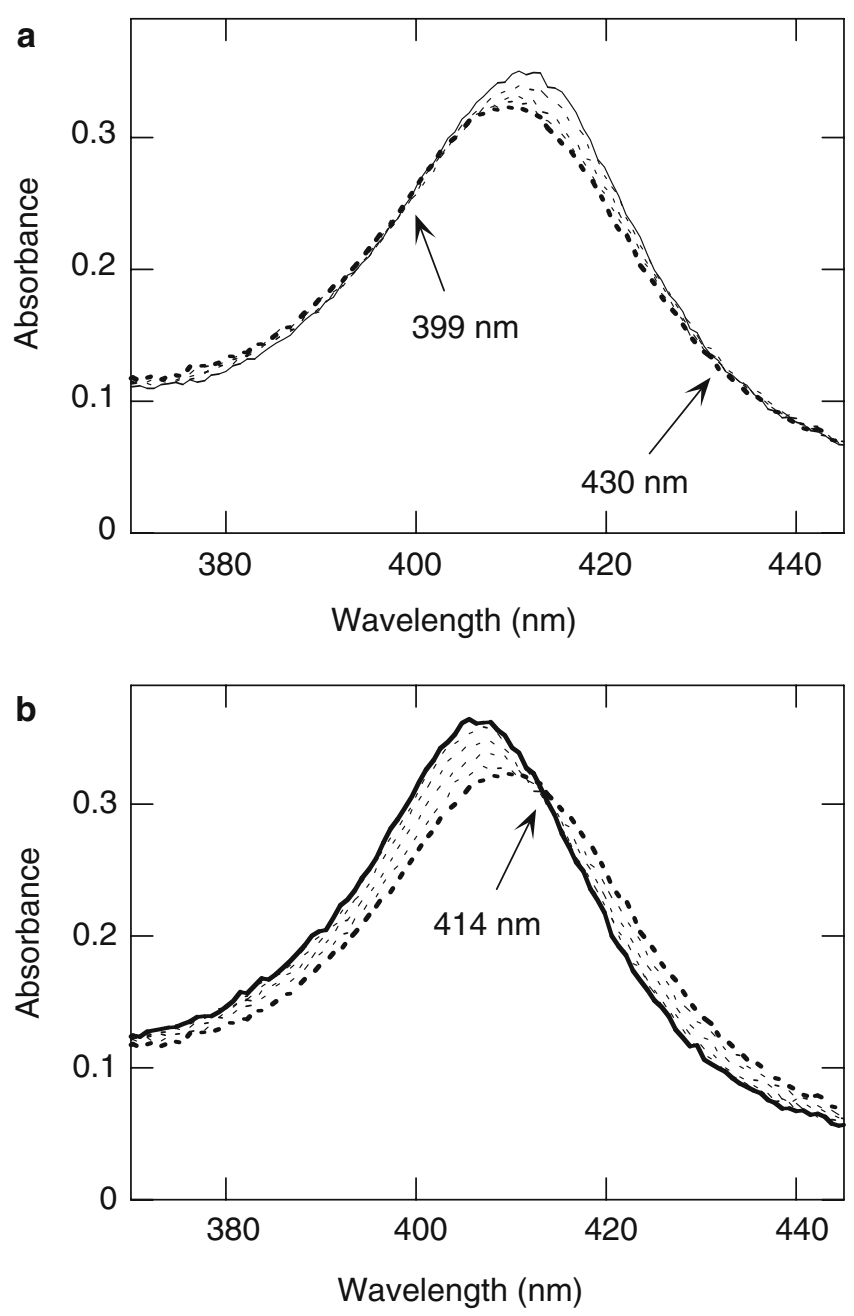

Fig. 4a-b Rapid-scan UV/vis spectra of the reaction of oxyLb $(3 \mu \mathrm{M})$ with peroxynitrite $(87 \mu \mathrm{M})$ in $0.05 \mathrm{M}$ phosphate buffer $\mathrm{pH}$ $7.3,20{ }^{\circ} \mathrm{C}$. Conversion of oxyLb (thin line) to the intermediate (bold dotted line) and to a mixture of $\mathrm{LbFe}^{\mathrm{III}} \mathrm{NO}_{2}$ metLb (bold line). a The spectra shown were collected over a time interval of $50 \mathrm{~ms}$. b The spectra shown were collected starting from $200 \mathrm{~ms}$ (dotted bold line) with a time interval of $150 \mathrm{~ms}$ addition of an excess of peroxynitrite to ferrylLb, the maximum of the Soret band shifts from 415 to $416 \mathrm{~nm}$ (characteristic for ferrylLb) to $405 \mathrm{~nm}$ ( $\lambda_{\max }$ of metLb). This conversion proceeds with a single isosbestic point at $414 \mathrm{~nm}$, the same wavelength of the isosbestic point found for the second step of the reaction between oxy Lb and peroxynitrite (Fig. 4b). The second-order rate constant of the reaction between ferrylLb and peroxynitrite was determined by fitting the reaction time courses at $420 \mathrm{~nm}$ to a single-exponential expression (Fig. 7b, inset). From a linear fit of the plot of the observed rate constants versus peroxynitrite concentration (Fig. 7b), we obtain a value of $(3.4 \pm 0.7) \times 10^{4} \mathrm{M}^{-1} \mathrm{~s}^{-1}$, very close to that for the second step of the reaction between peroxynitrite and oxyLb. Taken together, our results suggest that the reaction of peroxynitrite with oxyLb proceeds according to reactions 1 and 2; in other words,
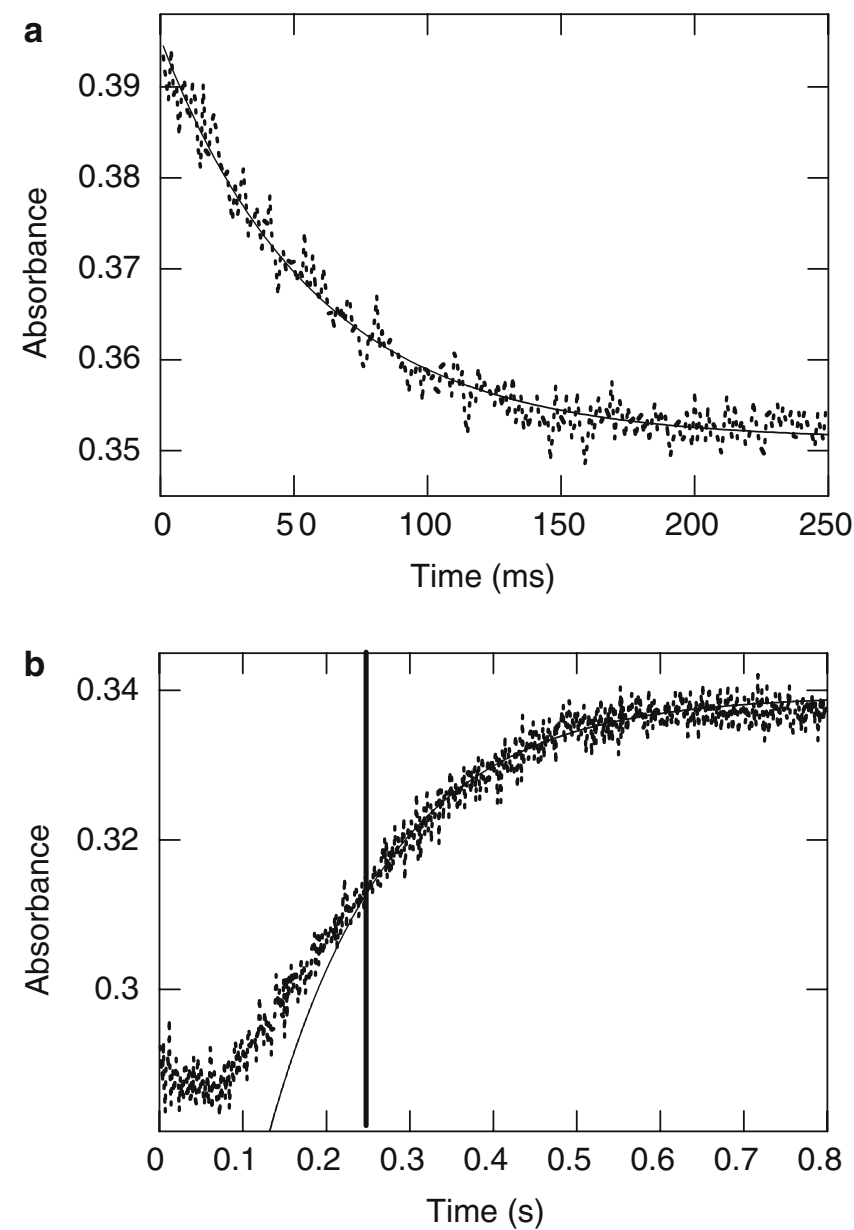

Fig. 5a-b Reaction time courses measured at a 413 and b $399 \mathrm{~nm}$ for the two steps of the reaction of $3 \mu \mathrm{M}$ oxyLb with $270 \mu \mathrm{M}$ peroxynitrite in $0.05 \mathrm{M}$ phosphate buffer $\mathrm{pH} 7.3$ and $20^{\circ} \mathrm{C}$. The dotted bold lines represent the experimental data, extracted from the rapid-scan UV/vis spectra. In (b), the vertical line indicates the starting point for the fit of the second step; that is, the point when the first step is finished. The two observed rate constants resulting from the best fits to the data (thin lines) are $17.4 \pm 0.5$ and $6.9 \pm 0.3 \mathrm{~s}^{-1}$, for the first (a) and the second (b) reaction step, respectively 


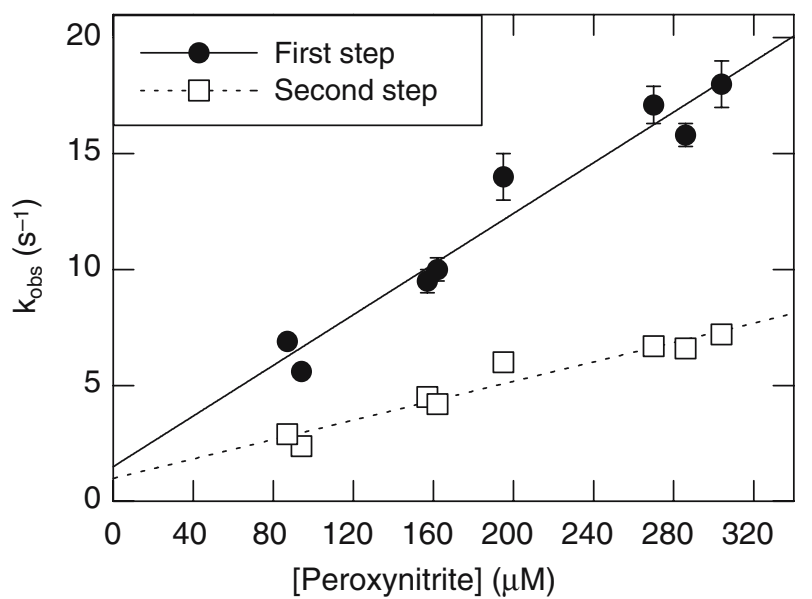

Fig. 6 Determination of the second-order rate constants for the two steps of the peroxynitrite-mediated oxidation of oxyLb. Plots of $k_{\text {obs }}$ versus peroxynitrite concentration for the two steps of the reaction between oxyLb $(3 \mu \mathrm{M})$ and peroxynitrite, followed at 413 / 414 or $399 / 430 \mathrm{~nm}$, respectively (in $0.05 \mathrm{M}$ phosphate buffer $\mathrm{pH}$ 7.3 at $\left.20^{\circ} \mathrm{C}\right)$

analogously to the reaction of peroxynitrite with human oxyHb [51] and horse heart oxyMb [39].

The reaction between oxyLb and peroxynitrite was also studied in the presence of $1.2 \mathrm{mM} \mathrm{CO}_{2}$. Rapid-scan $\mathrm{UV} /$ vis spectroscopic studies showed that the absorbance changes of the Soret band and of the visible part of the spectrum that occurred in the course of this reaction are essentially identical to those discussed above for the reaction in the absence of $\mathrm{CO}_{2}$ (data not shown). The kinetics of the two reaction steps were also studied separately by following the absorbance changes on two isosbestic points, 414 and $430 \mathrm{~nm}$, for the first and second step, respectively. As shown in Fig. 8, in the presence of $1.2 \mathrm{mM} \mathrm{CO}$ the observed rate constants increased linearly with increasing peroxynitrite concentration. The second-order rate constants obtained for the two steps from the linear fits shown are $(8.8 \pm 0.9) \times 10^{5}$ and $(3.6 \pm 0.5) \times 10^{5} \mathrm{M}^{-1} \mathrm{~s}^{-1}$, respectively. These values are one order of magnitude larger than those obtained for the two steps of the reaction that took place in the absence of $\mathrm{CO}_{2}$ (Table 1). Similar increases in the values of the rate constants were also found for the analogous reaction between human oxyHb and peroxynitrite (Table 1).

The second reaction step, the reduction of ferrylLb by peroxynitrite, was studied with separately prepared ferryLb, again in the presence of $1.2 \mathrm{mM} \mathrm{CO}$. The reaction time courses were measured at $420 \mathrm{~nm}$ (data not shown). For all peroxynitrite concentrations studied, the traces could be fitted to a single-exponential expression and the observed rate constants were very similar to those of the second step of the reaction between peroxynitrite and oxyLb measured under similar conditions. The second-order rate constant obtained from a linear fit of the plot of the observed rate constant versus peroxynitrite concentration (data not shown) is $(2.3 \pm 0.5) \times 10^{5} \mathrm{M}^{-1} \mathrm{~s}^{-1}$.
Catalysis of the decay of peroxynitrite by metLb

The reaction of metLb with peroxynitrite was studied by stopped-flow spectroscopy by following the absorbance changes at $302 \mathrm{~nm}$, the absorbance maximum of peroxynitrite. As shown in Fig. 9, at pH 7.3 and $20^{\circ} \mathrm{C}$, addition of $\sim 6 \mu \mathrm{M}$ of metLb reduced the half-life of the decay of $(100 \mu \mathrm{M})$ peroxynitrite from $t_{1 / 2}=3.5 \mathrm{~s}$ (in the absence of the protein) to $t_{1 / 2}=0.6 \mathrm{~s}$. Interestingly, under identical experimental conditions metLb was significantly more efficient than human metHb at catalyzing the decay of peroxynitrite (Fig. 9). The half-life for the
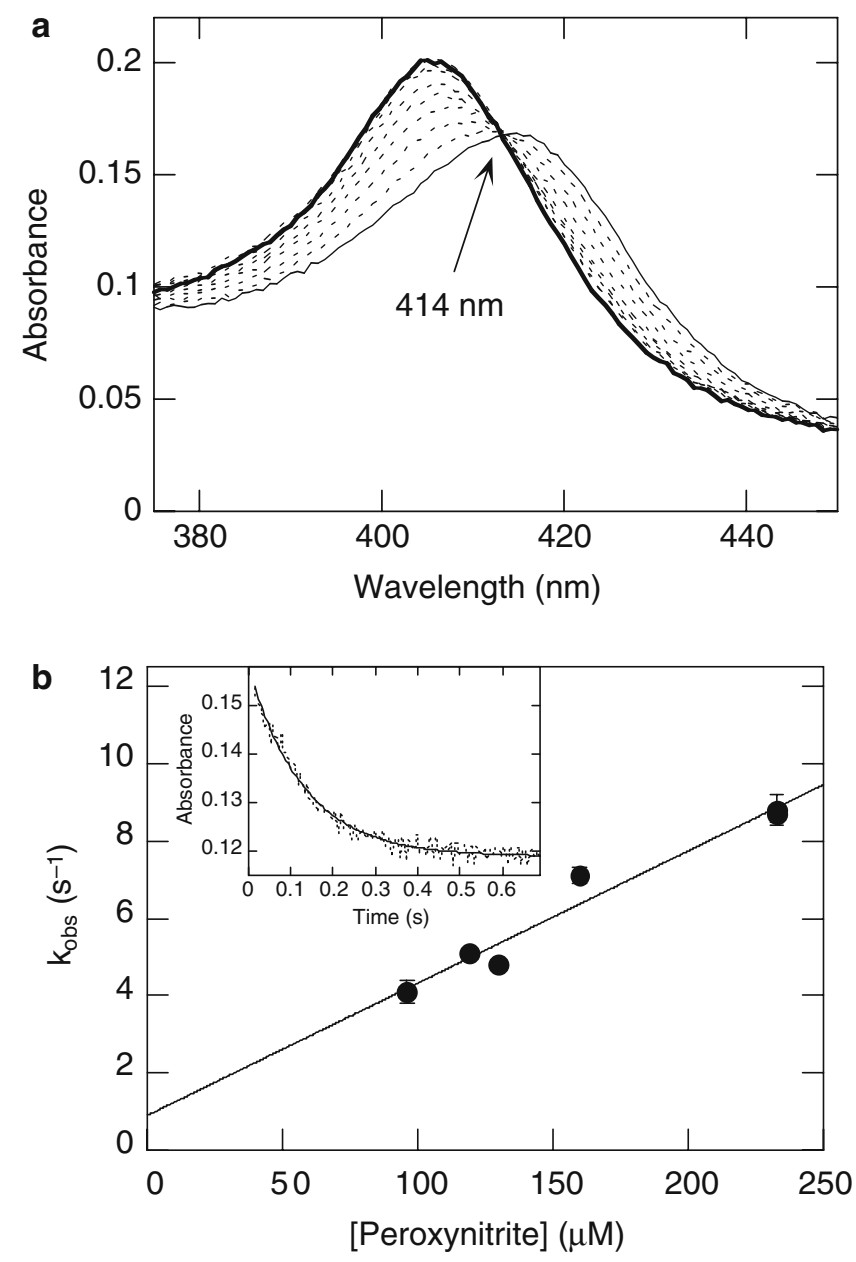

Fig. 7a-b Reaction of ferrylLb with peroxynitrite. a Rapid-scan $\mathrm{UV} /$ vis spectra of the reaction of ferrylLb $(2.2 \mu \mathrm{M})$ with peroxynitrite $(130 \mu \mathrm{M})$ in $0.05 \mathrm{M}$ phosphate buffer $\mathrm{pH} 7.3,20^{\circ} \mathrm{C}$. Conversion of ferrylLb (thin line) to metLb (bold line). The spectra shown were collected over a time interval of $50 \mathrm{~ms}$. b Determination of the second-order rate constant for the peroxynitritemediated reduction of ferrylLb. Plot of $k_{\mathrm{obs}}$ versus peroxynitrite concentration for the reaction between ferrylLb $(2-4 \mu \mathrm{M})$ and variable amounts of peroxynitrite, measured at $20{ }^{\circ} \mathrm{C}$ in $0.05 \mathrm{M}$ phosphate buffer $\mathrm{pH}$ 7.3. Inset Reaction time course measured at $420 \mathrm{~nm}$ for the reaction of $4 \mu \mathrm{M}$ ferrylLb with $160 \mu \mathrm{M}$ peroxynitrite in $0.05 \mathrm{M}$ phosphate buffer $\mathrm{pH} 7.3$ and $20^{\circ} \mathrm{C}$. The dotted bold line represents the experimental data, extracted from the rapid-scan $\mathrm{UV} / \mathrm{vis}$ spectra, and the thin line the best fit to the data $\left(k_{\mathrm{obs}}=7.3 \pm 0.3 \mathrm{~s}^{-1}\right)$ 


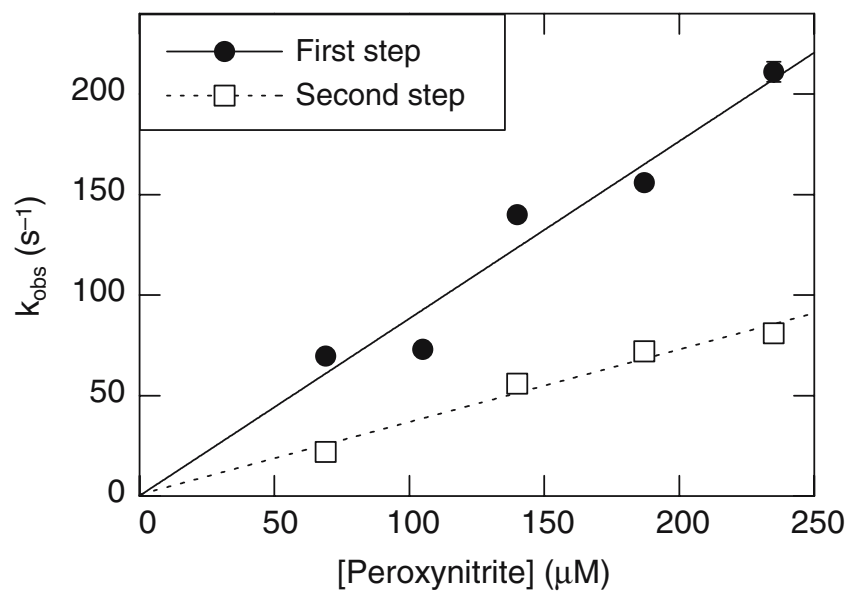

Fig. 8 Determination of the second-order rate constants for the two steps of the peroxynitrite-mediated oxidation of oxyLb in the presence of $\mathrm{CO}_{2}$. Plots of $k_{\mathrm{obs}}$ versus peroxynitrite concentration for the reaction between oxyLb $(3 \mu \mathrm{M})$ and peroxynitrite in the presence of $1.2 \mathrm{mM} \mathrm{CO}_{2}$, followed at 414 or $430 \mathrm{~nm}$, for the first and the second reaction steps, respectively (in $0.05 \mathrm{M}$ phosphate buffer, $\mathrm{pH} 7.4-7.5$ at $20{ }^{\circ} \mathrm{C}$ )

reaction performed under identical conditions but with $\sim 6 \mu \mathrm{M}$ metHb was $t_{1 / 2}=2.8 \mathrm{~s}$.

Experiments in the presence of variable amounts of metLb showed that the observed decay rate of peroxynitrite increased linearly with increasing protein concentration (Fig. 10). At pH 7.3 and $20^{\circ} \mathrm{C}$, the catalytic rate constant obtained from the linear fit shown in Fig. 10 was $(1.45 \pm 0.02) \times 10^{5} \mathrm{M}^{-1} \mathrm{~s}^{-1}$. This value is one order of magnitude larger than that previously reported for human metHb and horse heart metMb (Table 1) [37].

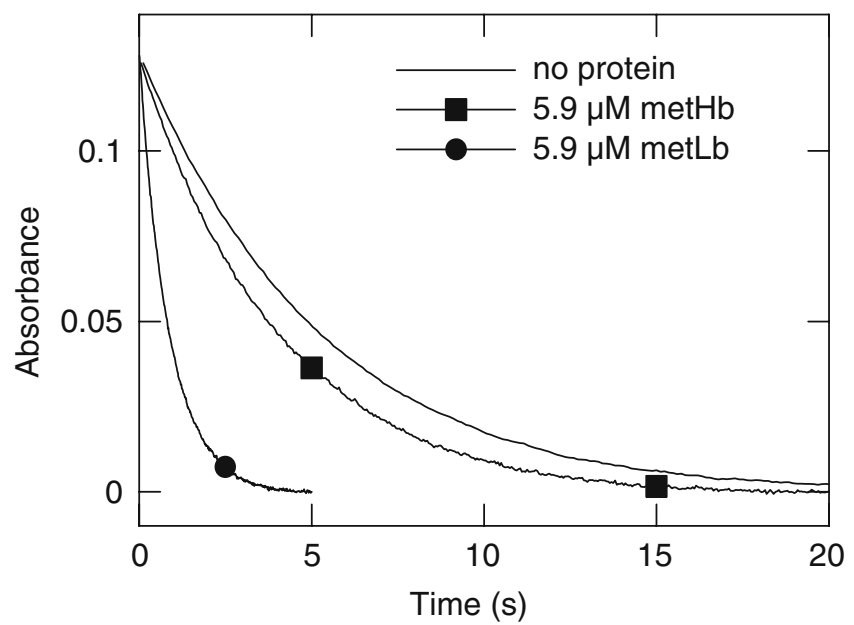

Fig. 9 Comparison of the efficiencies of human metHb and metLb at catalyzing the decay of peroxynitrite under identical experimental conditions. Absorbance decrease measured at $302 \mathrm{~nm}$ for the decay of $100 \mu \mathrm{M}$ peroxynitrite in the absence and presence of $5.9 \mu \mathrm{M}$ metLb or $5.9 \mu \mathrm{M}$ metHb, in $0.05 \mathrm{M}$ phosphate buffer $\mathrm{pH}$ 7.3 , at $20^{\circ} \mathrm{C}$
Analogous studies were carried out at $\mathrm{pH}$ 6.5. As shown in Fig. 10, at lower $\mathrm{pH}$ the rate constants observed for the decay of peroxynitrite were significantly larger, both in the absence and in the presence of metLb. Moreover, the efficiency of metLb to catalyze the decay of peroxynitrite also increased. Indeed, the catalytic rate constant obtained from the linear fit at $\mathrm{pH} 6.5$ and $20{ }^{\circ} \mathrm{C}$ was $(5.15 \pm 0.02) \times 10^{5} \mathrm{M}^{-1} \mathrm{~s}^{-1}$. This result suggests that, analogous with the reaction with human metHb [37], peroxynitrous acid (HOONO) is the species that reacts with metLb. Interestingly, under acidic conditions the catalytic rate constant for metLb is one order of magnitude larger than that for human metHb, which is $(2.3 \pm 0.1) \times 10^{4} \mathrm{M}^{-1} \mathrm{~s}^{-1}$ (at pH 6.5 and $20^{\circ} \mathrm{C}$ [37]).

The reaction of peroxynitrite with metLb was also studied by following the absorbance changes at different wavelengths on the Soret band (404, 411, and $415 \mathrm{~nm}$ ). In analogy with the reaction with human metHb, the time courses did not only show the decay of peroxynitrite, which still absorbs in this range (because of its very broad band with $\lambda_{\max }=302 \mathrm{~nm}$ ). In most cases, one or two additional processes were observed, which took place at a faster rate than that of peroxynitrite decay (data not shown). The absorbance changes linked with these processes are small and it is possible that they represent the binding of peroxynitrite to metLb.

In addition, further absorbance changes were detected over a much longer timescale (up to $500 \mathrm{~s}$ ). The directions of these changes (increase/decrease) indicated that they did not arise from the reaction of metLb with nitrite, always present as a contaminant in our peroxynitrite solutions (see below). Because of the large excess of peroxynitrite over metLb used in these experiments, it is conceivable that a fraction of peroxynitrite eludes the reaction with the heme and thus leads to modification of the amino acid residues of $\mathrm{Lb}$. Indeed, the analogous

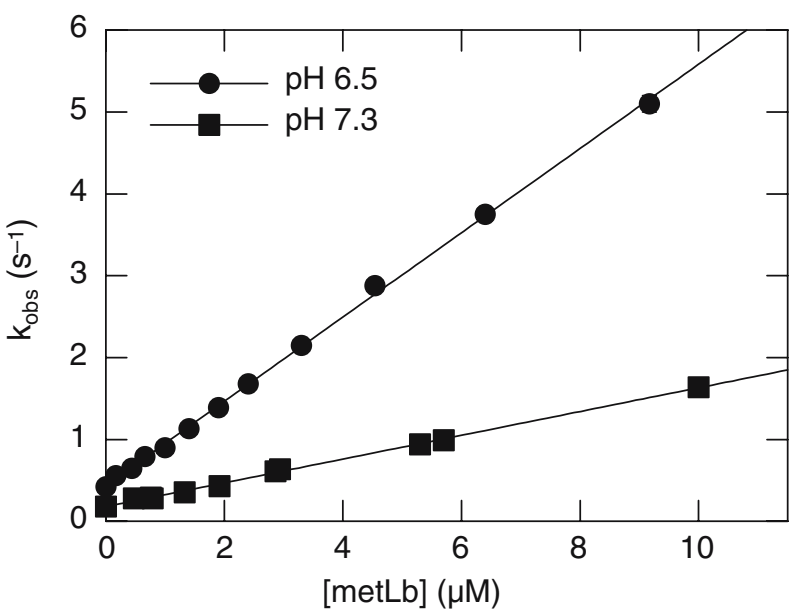

Fig. 10 Determination of the catalytic rate constant for the metLbmediated decay of peroxynitrite. Plot of $k_{\mathrm{obs}}$ versus metLb concentration for the protein-catalyzed decay of peroxynitrite $(100 \mu \mathrm{M})$, measured at $20^{\circ} \mathrm{C}$ in $0.05 \mathrm{M}$ phosphate buffer $(\mathrm{pH} 6.5$ and 7.3) 
reaction of metHb with an excess of peroxynitrite leads to the formation of a long-lived radical characterized by EPR spectroscopy and assigned as a tyrosyl radical [53]. Moreover, similar studies carried out with distal histidine sperm whale metMb mutants also showed the formation of small amounts of nitrated tyrosine residues in those mutants that displayed similar or even larger values of catalytic rate constants for peroxynitrite isomerization [54]. Thus, the absorbance changes detected in our experiments with metLb when peroxynitrite had already completely decayed may arise from subsequent reactions of reactive (radical) intermediates generated on the globin, which slightly modify the absorbance features of the Soret band. Nevertheless, the $\lambda_{\max }$ of metLb was unchanged at the end of the reaction, an observation that suggests that these subsequent reactions are minor processes. In conclusion, since these reactions are certainly due to the large quantities of peroxynitrite used in our experiments, which are significantly larger than those possibly generated in plants, we decided not to investigate them further.

\section{Discussion}

Leghemoglobins are the most extensively studied oxygen-binding hemoproteins in plants, as $\mathrm{Hb}$ and $\mathrm{Mb}$ are for vertebrates. The major function of $\mathrm{Lb}$ is undoubtedly to guarantee oxygen supply to respiring nitrogenfixing microsymbionts at very low oxygen concentrations $(10 \mathrm{nM})$ [4]. However, the discovery that $\mathrm{NO}^{\bullet}$ is also produced in plants may reveal further roles for $\mathrm{Lb}$, related to the biochemistry of so-called reactive nitrogen species, as has happened for $\mathrm{Hb}$ and $\mathrm{Mb}[22,55,56]$. Indeed, it has recently been demonstrated that besides $\mathrm{O}_{2}$ uptake and storage, $\mathrm{Hb}$ and $\mathrm{Mb}$ also act as $\mathrm{NO}^{\bullet}$ and peroxynitrite scavengers [38, 39, 49].

In plants, one of the functions of $\mathrm{NO}^{\bullet}$ is to act as an essential messenger in defense signaling against pathogens [11]. The detection of nitrosyl $\mathrm{Lb}$ in nodules [30-32] strongly suggests that $\mathrm{NO}^{\bullet}$ is also formed in functional nodules. This has recently been confirmed by experiments performed in our laboratories with a fluorescent probe (A. Puppo, unpublished results). Moreover, NO may react with superoxide, which may be produced in nodules by various processes [33, 34, 57], thus leading to the formation of peroxynitrite. Since hemoproteins are among the major targets of $\mathrm{NO}^{\bullet}$ and peroxynitrite in vivo, in this work we studied the reactions of different forms of soybean $\mathrm{Lb}$ with these two so-called reactive nitrogen species, focusing particularly on the physiologically active oxyLb form.

The kinetics studies presented here show that the reaction of $\mathrm{NO}^{\bullet}$ with oxyLb is comparable to those with oxyHb and oxyMb. Indeed, the reaction proceeds via ferrylLb, the final product is metLb, and the values of the second-order rate constant are all of the same order of magnitude (Table 1). Detailed studies with $\mathrm{Mb}$ mutants have revealed that, because of the high chemical reactivity of $\mathrm{NO}^{\bullet}$ towards the oxygenated heme center, diffusion of $\mathrm{NO}^{\bullet}$ into the distal pocket is very likely to be the rate-limiting step for this reaction [58-60]. The same argument holds for the binding of $\mathrm{NO}^{\bullet}$ to deoxygenated forms of hemoglobins and myoglobins. Indeed, a good correlation has been found between the values of the rate constants for $\mathrm{NO}^{\circ}$-mediated oxidations of several oxyMb mutants in which residues of the distal pocket were replaced and those of $\mathrm{NO}^{\bullet}$ binding to the corresponding deoxygenated proteins [58]. This observation supports the hypothesis of a common rate-limiting step. The value of the second-order rate constant for $\mathrm{NO}^{\circ}$ binding to deoxyLb $\left(1.2 \times 10^{8} \mathrm{M}^{-1} \mathrm{~s}^{-1}\right.$, [61]) is four times larger than that of the reaction between the two subunits of deoxyHb and $\mathrm{NO}^{\bullet}\left(3.0 \times 10^{7} \mathrm{M}^{-1} \mathrm{~s}^{-1}\right.$, [62]). According to this hypothesis, the observation that the $\mathrm{NO}^{\bullet}$ mediated oxidations of oxy Lb and oxyHb proceed at comparable rates is unexpected. Indeed, it would have been predicted that the second-order rate constant for the $\mathrm{NO}^{\bullet}$-mediated oxidation of oxyLb is four times larger than that for the corresponding reaction with oxyHb.

The amino acid sequence of soybean leghemoglobin shows a high degree of homology with those of vertebrate myoglobins and hemoglobins [4]. Also, its tertiary folding pattern is very similar to that of $\mathrm{Mb}$ and of the $\alpha$ and the $\beta$-subunits of human $\mathrm{Hb}[63,64]$. Moreover, soybean $\mathrm{Lb}$ contains two histidine residues in positions analogous to those of the "proximal" and "distal" histidine of mammalian $\mathrm{Hb}$ and $\mathrm{Mb}$. In oxyHb and oxy$\mathrm{Mb}$, the distal histidine is strongly hydrogen bonded to the coordinated oxygen, a feature that will lead to stabilization of the $\mathrm{Fe}^{\mathrm{III}} \mathrm{O}_{2}^{--}$resonance structure (vs. $\mathrm{Fe}^{\mathrm{II}} \mathrm{O}_{2}$ ). In contrast, kinetics studies with distal histidine Lb mutants (His61 in soybean Lb) [63] as well as spin echo EPR studies [65] showed that the hydrogen bond between the distal histidine and the coordinated $\mathrm{O}_{2}$ in oxyLb is very weak at neutral $\mathrm{pH}$ and becomes strong only at low pH. Consequently, in oxyLb the $\mathrm{Fe}^{\mathrm{III}} \mathrm{O}_{2}^{\circ-}$ resonance structure is likely to be less stabilized and so radical recombination reaction with $\mathrm{NO}^{\bullet}$ may proceed at a slightly slower rate.

In analogy to the reaction of $\mathrm{NO}^{\bullet}$ with oxyHb and oxyMb $[49,66]$, it is conceivable that the metLb-peroxynitrite complex ( $\mathrm{LbFe}^{\mathrm{III}} \mathrm{OONO}$ ) is formed in the first step of the corresponding reaction with oxyLb. However, no intermediate could be detected in our stoppedflow studies, even under conditions that allowed for the spectroscopic characterization of the corresponding human $\mathrm{Hb}$ complex ( $\mathrm{pH}$ 9.5) [50, 66]. Our previous studies with $\mathrm{Hb}$ and $\mathrm{Mb}$ suggested that the rate of decay of the intermediate iron(III) peroxynitrite complex is strongly influenced by the protein environment surrounding the heme $[49,66]$. Indeed, significant differences were observed among the decay rates of the peroxynitrite complexes of metMb and the iron(III) forms of the two subunits of $\mathrm{Hb}$ : at $\mathrm{pH} 9.5$ and $20{ }^{\circ} \mathrm{C}$, the values are 205,47 , and $6.9 \mathrm{~s}^{-1}$, respectively [49]. 
A significant difference between the structures of $\mathrm{Hb} / \mathrm{Mb}$ and $\mathrm{Lb}$ is the presence of a wider and more flexible heme pocket in Lb [63, 64]. Thus, the observation that LbFe ${ }^{\mathrm{III}} \mathrm{OONO}$ decays at a considerably larger rate than the corresponding $\mathrm{Mb}$ and $\mathrm{Hb}$ complexes seems to suggest that isomerization to nitrate is facilitated when the distal pocket is wider. Studies with distal histidine mutants of $\mathrm{Mb}$ (or $\mathrm{Lb}$ ) would help to corroborate this hypothesis.

The average concentration of $\mathrm{Lb}$ over the entire nodule is $\sim 300 \mu \mathrm{M}$. However, in very active nodules its local concentration can reach 2-3 mM [4]. In biological systems, $\mathrm{Lb}$ is mainly present in the reduced $\mathrm{LbFe}^{\mathrm{II}}$ form. Indeed, because of the low oxygen tension in root nodules, only $\sim 35 \%$ of $\mathrm{Lb}$ is found in the oxygenated form (oxyLb) [67]. Even if a large part of $\mathrm{NO}^{\bullet}$ did bind to deoxyLb, the $\mathrm{NO}^{\bullet}$ scavenging activity of oxyLb would be noticeable. Both processes would protect nitrogenase, which is rapidly inhibited by $\mathrm{NO}^{\bullet}$ [29]. Moreover, it has been shown that some Lb genes are induced early in the symbiotic interaction [68], before nitrogenase is expressed. At this stage, the oxygen concentration may still be high and larger amounts of $\mathrm{Lb}$ may be in the oxygenated form. Under these conditions, the $\mathrm{NO}^{\bullet}$ scavenging activity of oxyLb would preclude any triggering of a plant defense reaction by this reactive species.

The protective role of oxyLb may be even greater against the damaging effects of peroxynitrite. In nodules, superoxide formation may occur from $\mathrm{Lb}$ autoxidation [34] and as a result of the strong reducing conditions required for nitrogen fixation and the action of several proteins including ferredoxin, uricase and hydrogenase [33]. Thus, peroxynitrite is also likely to be produced in functional nodules. Our kinetics studies show that oxyLb is a good scavenger for peroxynitrite. Indeed, the half-life of peroxynitrite in the presence of $1 \mathrm{mM}$ oxyLb is $\sim 10 \mathrm{~ms}$. Moreover, it has been reported that the $\mathrm{CO}_{2}$ concentration in active nodules is about $1.3 \mathrm{mM}$ [69]. Our studies in the presence of $1.2 \mathrm{mM} \mathrm{CO}_{2}$ showed that oxyLb is even more efficient under these conditions: $1 \mathrm{mM}$ oxyLb reacts with peroxynitrite with a half-life of $\sim 1 \mathrm{~ms}$. The mechanism of the reaction between oxyLb and peroxynitrite seems to be identical to that between oxyHb and peroxynitrite. Thus, our work shows that, particularly in the presence of $\mathrm{CO}_{2}$, oxyLb can not only scavenge peroxynitrite but also the radicals derived from its decomposition: $\mathrm{CO}_{3}^{\bullet}$ and $\mathrm{NO}_{2}^{\bullet}$.

Because of the high affinity of deoxyLb for $\mathrm{O}_{2}$, with the stopped-flow instruments at our disposal it was not possible to determine the rate constant of its reaction with peroxynitrite. To get qualitative information, we added 5 equiv. of peroxynitrite to deoxyLb under strictly anaerobic conditions in a UV/vis cell, and we have confirmed that metLb is produced from this reaction (data not shown). We have previously shown that the reactions of peroxynitrite with deoxyMb and deoxyHb proceed at a similar rate $(\mathrm{Hb})$ or faster $(\mathrm{Mb})$ than those with the oxygenated forms of these proteins
$[39,51]$. Thus, even if Lb was mostly in its deoxygenated form, it may still be an efficient peroxynitrite scavenger.

Interestingly, most extracts from root nodules contain some amount of the oxidized iron(III) form of $\mathrm{Lb}$ (metLb). It has been argued that Lb may be oxidized during the extraction process $[4,67]$. Nevertheless, direct evidence for metLb occurrence in soybean nodules, in particular in old nodules, has been presented by carrying out UV/vis spectroscopic measurements of intact nodules attached to roots [70].

Here, we have shown that metLb catalyzes the isomerization of peroxynitrite to nitrate, analogously to metHb or metMb. Nevertheless, metLb is ten times more active. We have previously shown that the efficiencies of metHb and metMb as peroxynitrite isomerization catalysts are strongly affected by the presence of the hydrogen bond between the distal histidine and the $\mathrm{H}_{2} \mathrm{O}$ molecule bound to the iron(III) center [37, 54, 71]. This strong hydrogen bond has to be cleaved in the ratedetermining step of the catalytic process: peroxynitrite binding to the iron(III) center. Thus, metMb mutants in which this hydrogen bond is absent are much more efficient catalysts for the isomerization of peroxynitrite to nitrate $[54,71]$.

Studies with distal histidine metLb mutants have suggested that this residue undergoes hydrogen bonding to the water molecule coordinated to the iron(III) center in $\mathrm{Lb}$ as well [63, 72]. However, it has been shown that this hydrogen bond is weaker in metLb than those in metMb and metHb [63, 72]. Moreover, the position of the Soret absorbance maximum of metLb (404 nm) indicates that the water molecule is only weakly bound to the iron(III). Taken together, the wider, more flexible heme pocket and the weaker hydrogen bond offer an explanation for the larger value of the catalytic rate constant obtained for metLb. Nevertheless, the value of $k_{\text {cat }}$ is still more than one order of magnitude smaller than those of the H64A- and H64D-metMb mutants [54], proteins in which this hydrogen bond is absent.

It is interesting to note that the reactivity of metLb towards peroxynitrite is very different to that towards another oxidant generated in plants, $\mathrm{H}_{2} \mathrm{O}_{2}$. Indeed, exposure of metLb to $\mathrm{H}_{2} \mathrm{O}_{2}$ results in the formation of the highly valent oxoiron(IV) form $\left(\mathrm{LbFe}^{\mathrm{IV}}=\mathrm{O}\right)$ and one or more radicals on the globin [48]. In addition, a green compound is produced, which is believed to be a cross-linked species produced from the reaction of a globin radical with the heme [73].

The results presented here clearly show that oxyLb is able to scavenge any $\mathrm{NO}^{\bullet}$ formed in functional nodules. This may contribute to the protection of nitrogenase, which is rapidly inactivated by this reactive species [29]. OxyLb is also able to scavenge peroxynitrite, which is likely to be produced from the reaction of $\mathrm{NO}^{\bullet}$ with superoxide formed in nodules [33, 34, 57], precluding any damaging effect of this species. In both cases, the metLb generated can be reduced by a metLb reductase [74] to its ferrous form, which can give rise to oxyLb. Thus, oxyLb may have a protective role against these 
reactive species in functional nodules. On the other hand, taking into account the early inductions of some $\mathrm{Lb}$ genes [68], a possible role in the nodulation process cannot be excluded.

\section{References}

1. Kubo H (1939) Acta Phytochim (Tokyo) 11:195-200

2. Appleby CA, Bogusz D, Dennis ES, Peacock WJ (1988) Plant Cell Environ 11:359-367

3. Dordas C, Rivoal J, Hill RD (2003) Ann Bot 91:173-178

4. Davies MJ, Mathieu C, Puppo A (1999) Adv Inorg Chem 46:495-542

5. Hunt PW, Watts RA, Trevaskis B, Llewellyn DJ, Burnell J, Dennis ES, Peacock WJ (2001) Plant Mol Biol 47:677-692

6. Watts RA, Hunt PW, Hvitved AN, Hargrove MS, Peacock WJ, Dennis ES (2001) Proc Natl Acad Sci USA 98:1011910124

7. Wittenberg JB, Bolognesi M, Wittenberg BA, Guertin M (2002) J Biol Chem 277:871-874

8. Moncada S, Palmer RMJ, Higgs EA (1991) Pharmacol Rev 43:109-142

9. Alderton WK, Cooper CE, Knowles RG (2001) Biochem J 357:593-615

10. Beligni MV, Lamattina L (2001) Plant Cell Environ 24:267-278

11. Wendehenne D, Durner J, Klessig DF (2004) Curr Opin Plant Biol 7:449-455

12. Neill S, Desikan R, Hancock JT (2003) New Phytol 159:11-35

13. Butt YK-C, Lum JH-K, Lo SC-L (2003) Planta 216:762-771

14. Yamasaki H, Sakihama Y, Takahashi S (1999) Trends Plant Sci 4:128-129

15. Desikan R, Griffiths R, Hancock J, Neill S (2002) Proc Natl Acad Sci USA 99:16314-16318

16. Meyer C, Lea US, Provan F, Kaiser WM, Lillo C (2005) Photosynth Res 83:181-189

17. Kaiser WM, Weiner H, Kandlbinder A, Tsai C-B, Rockel P, Sonoda M, Planchet E (2002) J Exp Bot 53:875-882

18. Romero-Puertas MC, Perazzolli M, Zago ED, Delledonne M (2004) Cell Microbiol 6:795-803

19. Durner J, Wendehenne D, Klessig DF (1998) Proc Natl Acad Sci USA 95:10328-10333

20. Delledonne M, Xia Y, Dixon RA, Lamb C (1998) Nature 394:585-588

21. Guo F-Q, Okamoto M, Crawford NM (2003) Science 302:100103

22. Herold S (2003) C R Biol 326:533-541

23. Poole RK (2005) Biochem Soc Trans 33:176-180

24. Dordas C, Hasinoff BB, Igamberdiev AU, Manac'h N, Rivoal J, Hill RD (2003) Plant J 35:763-770

25. Igamberdiev AU, Seregelyes CS, Manac'h N, Hill RD (2004) Planta 219:95-102

26. Zottini M, Formentin E, Scattolin M, Carimi F, Lo Schiavo F, Terzi M (2002) FEBS Lett 515:75-78

27. Dordas C, Hasinoff BB, Rivoal J, Hill RD (2004) Planta 219:66-72

28. Cueto M, Hernandez-Perera O, Martin R, Bentura ML, Rodrigo J, Lamas S, Golvano MP (1996) FEBS Lett 398:159-164

29. Meyer J (1981) Arch Biochem Biophys 210:246-256

30. Mathieu C, Moreau S, Frendo P, Puppo A, Davies MJ (1998) Free Radic Biol Med 24:1242-1249

31. Maskall CS, Gibson JF, Dart PJ (1977) Biochem J 167:435-445

32. Hérouart D, Baudouin E, Frendo P, Harrison J, Santos R, Jamet A, Van de Sype G, Touati D, Puppo A (2002) Plant Physiol Biochem 40:619-624

33. Dalton DA, Post CJ, Langeberg L (1991) Plant Physiol 96:812818
34. Puppo A, Rigaud J, Job D (1981) Plant Sci Lett 22:353-360

35. Nauser T, Koppenol WH (2002) J Phys Chem A 106:4084-4086

36. Radi R, Peluffo G, Alvarez MN, Naviliat M, Cayota A (2001) Free Radic Biol Med 30:463-488

37. Herold S, Shivashankar K (2003) Biochemistry 42:14036-14046

38. Herold S, Shivashankar K, Mehl M (2002) Biochemistry 41:13460-13472

39. Exner M, Herold S (2000) Chem Res Toxicol 13:287-293

40. Herold S, Exner M, Boccini F (2003) Chem Res Toxicol 16:390-402

41. Herold S, Röck G (2003) J Biol Chem 278:6623-6634

42. Koppenol WH, Kissner R, Beckman JS (1996) Methods Enzymol 269:296-302

43. Bohle DS, Glassbrenner PA, Hansert B (1996) Methods Enzymol 269:302-311

44. Rigaud J, Puppo A (1977) Biochim Biophys Acta 497:702-706

45. Herold S, Puppo A (2005) J Biol Inorg Chem (this issue)

46. Harned HS, Bonner FT (1945) J Am Chem Soc 67:1026-1031

47. Puppo A, Rigaud J (1987) Electrophoresis 8:212-214

48. Aviram I, Wittenberg A, Wittenberg JB (1978) J Biol Chem 253:5685-5689

49. Herold S, Exner M, Nauser T (2001) Biochemistry 40:33853395

50. Olson JS, Foley EW, Rogge C, Tsai AL, Doyle ML, Lemon DD (2004) Free Radic Biol Med 36:685-697

51. Boccini F, Herold S (2004) Biochemistry 43:16393-16404

52. Everse J, Hsia N (1997) Free Radic Biol Med 22:1075-1099

53. Pietraforte D, Salzano AM, Scorza G, Marino G, Minetti M (2001) Biochemistry 40:15300-15309

54. Herold S, Kalinga S, Matsui T, Watanabe Y (2004) J Am Chem Soc 126:6945-6955

55. Gladwin MT, Crawford JH, Patel RP (2004) Free Radic Biol Med 36:707-717

56. Brunori M (2001) Trends Biochem Sci 26:209-210

57. Santos R, Hérouart D, Sigaud S, Touati D, Puppo A (2001) Mol Plant-Microbe Interact 14:86-89

58. Eich RF, Li T, Lemon DD, Doherty DH, Curry SR, Aitken JF, Mathews AJ, Johnson KA, Smith RD, Phillips GN Jr, Olson JS (1996) Biochemistry 35:6976-6983

59. Scott EE, Gibson QH, Olson JS (2001) J Biol Chem 276:51775188

60. Quillin ML, Li T, Olson JS, Phillips GN Jr, Dou Y, IkedaSaito M, Regan R, Carlson M, Gibson QH, Li H, Elber R (1995) J Mol Biol 245:416-436

61. Rohlfs RJ, Olson JS, Gibson QH (1988) J Biol Chem 263:18031813

62. Olson JS, Rohlfs RJ, Gibson QH (1987) J Biol Chem 262:12930-12938

63. Hargrove MS, Barry JK, Brucker EA, Berry MB, Phillips GN Jr, Olson JS, Arredondo-Peter R, Dean JM, Klucas RV, Sarath G (1997) J Mol Biol 266:1032-1042

64. Ollis DL, Appleby CA, Colman PM, Cutten AE, Guss JM, Venkatappa MP, Freeman HC (1983) Aust J Chem 36:451-468

65. Lee HC, Wittenberg JB, Peisach J (1993) Biochemistry 32:11500-11506

66. Herold S (1999) FEBS Lett 443:81-84

67. Becana M, Klucas RV (1991) Plant Physiol 98:1217-1221

68. Downie JA (2005) Curr Biol 15:R196-R198

69. Hunt S, Gaito ST, Layzell DB (1988) Planta 173:128-141

70. Lee K-K, Shearman LL, Erickson BK, Klucas RV (1995) Plant Physiol 109:261-267

71. Herold S, Matsui T, Watanabe Y (2001) J Am Chem Soc 123:4085-4086

72. Kundu S, Hargrove MS (2003) Proteins 50:239-248

73. Moreau S, Davies MJ, Puppo A (1995) Biochim Biophys Acta 1251:17-22

74. Ji L, Becana M, Sarath G, Shearman L, Klucas RV (1994) Plant Physiol 106:203-209 